\title{
GENETIC DIVERSITY OF CURCUMA IN THAILAND USING EXTERNAL TRANSCRIBED SPACER (ETS) SEQUENCES
}

\section{PATTAMON SANGIN \& PREEYANIT MONGKHOLSATHIAN}

Department of Biology, Faculty of Science, Naresuan University, Thailand

\begin{abstract}
The Curcuma is the largest genus of Zingiberaceae which has been widely used as an important medicinal plants, spices and cosmetics. Consequently, genetic diversity from 22 samples of Curcuma was analyzed using the 5' region of the external transcribed spacer (ETS) of 18S-26S nuclear ribosomal DNA sequences. The DNA sequences varied in length from 579-583bp. Neighbor-Joining (NJ) with Kimura -2-parameter was used to reconstruct phylogenetic trees. The genetic distance among samples ranged from 0.003-0.134. Curcuma was monophyletic entities based on ETS analyses. The phylogenetic tree showed that 22 samples of Curcuma could be separated into 2 groups with high bootstrap support. The most genetic similarity was found between C. aeruginosa and Curcuma sp. 1 which is consistent with the geographical distribution. The high bootstrap support (97\%) indicated that Curcuma sp. 5, Curcuma sp. 6, Curcuma sp. 7, C. amada 1, C. amada 2, C. amada 3 and C. amada 4 were closely related species. This study represented the potential of ETS as a good candidate region for phylogenetic analysis of Curcuma species.

KEYWORDS: Genetic Diversity, Curcuma \& External Transcribed Spacer (ETS)
\end{abstract}

Received: Aug 28, 2017; Accepted: Sep 20, 2017; Published: Sep 25, 2017; Paper Id.: IJASROCT201738

\section{INTRODUCTION}

Curcuma belonging to the family Zingiberaceae or Ginger family has around 120 species distributed throughout the tropical and subtropical regions of the world (Wu and Larsen, 2000). C. longa L. (Turmeric) being the best-known species which curcumin, a substance in turmeric. It is commonly used as traditional medicines for many countries in Asia. Several studies suggest that it might ease symptoms of osteoarthritis and rheumatoid arthritis, like pain and inflammation. Other compounds in turmeric might also be medicinal (Záveská et al., 2012). The taxonomic identification of the genus is difficult because of morphological variation at the intraspecific level. In addition the flowering season of Curcuma species is short and the floral morphology has higher similarity among the species, but differs in colors and inflorescence positions. Previous studies focused on identification of Curcuma plants, medical and chemical compound. The relationship amongst Curcuma species using only morphological characters remains unclear. Therefore, an understanding of genetic diversity for breeding programs and plant genetic resource conservation is needed.

Recent molecular markers are a powerful technique for investigating the genetic diversity of plants due to independent of the influence of the environment (Murty et al., 2013). Molecular markers reveal polymorphism that used to study genetic relationships and genetic diversity in several plants. The ribosomal RNA (rRNA) genes and the intergenic spacer (IGS) of ribosomal RNA (the non-transcribed spacer (NTS) and external transcribed spacer (ETS)) have become widely used as a good source of phylogenetic information (Dixon and Hillis, 1993). The ETS has represented a potential data in phylogenetic studies of angiosperms (Alonso, 2014; Linder et al., 2000). The 
polymorphisms of ETS region of $18 \mathrm{~S}-26 \mathrm{~S}$ of nuclear DNA (nrDNA) are good tools for identified the relationship of closely related taxes in many plant groups which DNA sequence of the 5' region of the ETS has a greater amount of variation than that of the ITS. (Markos and Baldwin, 2001; Hidalgo et al., 2006). In this study, we designed ETS primers that amplified the entire ETS throughout Curcuma and represented the genetic diversity of Curcuma in Thailand.

\section{MATERIALS AND METHODS}

\section{Plant Materials}

21 samples of Curcuma were collected from northern and 1 sample was collected from the northeastern region of Thailand (Table 1). Zingibermontanum was included in the analysis as an out-group. These plants were cultivated in Department of Biology, Faculty of Science, Naresuan University and the leaf samples were used for DNA extraction.

\section{DNA Extraction, PCR Amplification and DNA Sequencing}

Total genomic DNA was extracted from the young leaves of twenty-three samples using CTAB method (Dhakshanamoorthy and Selvaraj, 2009). The External Transcribed Spacer (ETS) region was amplified by primer 18SrRNA_ETS_R (GCCATTCGCAGTTTCACAAT) and ETS_F (TTTGCAAGTCGTGTGAGTT). PCR amplification was performed with18S rRNA External Transcribed Spacer (ETS primers). Reactions were carried out in a total volume of $20 \mu \mathrm{l}$ consisting of $100 \mathrm{ng}$ of template DNA, 1X PCR buffer, $2.5 \mathrm{mM} \mathrm{MgCl}$, $0.1 \mathrm{mMdNTPs}, 200 \mathrm{nM}$ primers, 1.0 unit of Taq polymerase and sterile water. Amplifications were made in a Perkin Elmer 9600 thermocycler with an initial denaturing step of $3 \mathrm{~min}$ at $94{ }^{\circ} \mathrm{C}$, followed by 35 cycles of $30 \mathrm{~s}$ at $94^{\circ} \mathrm{C}, 45 \mathrm{~s}$ at $52^{\circ} \mathrm{C}, 1 \mathrm{~min}$ at $72^{\circ} \mathrm{C}$ and a final extension of $5 \mathrm{~min}$ at $72^{\circ} \mathrm{C}$. PCR products were separated by electrophoresis on $1 \%$ agarose gels in TBE buffer and visualized using ethidium bromide staining. PCR products were purified with the Nucleospin ${ }^{\circledR}$ Gel and PCR cleanup kit (MACHEREYNAGEL, Germany) and directly sequenced at Macrogen Inc. (http://www.macrogen.com).

\section{Data Analysis}

Sequences were edited and assembled using the program Gene studio (Gene studio, Inc). The assembled contigs of species were initially aligned using Clustal W (Thompson et al., 1994) multiple sequence alignment software. The data were imported to a GENEDOC 2.6 (Nicholas et al., 1997) and manually adjusted. Neighbor-joining (NJ) was constructed using MEGA 7 program (Kumar et al., 2016). Clustering of species of each tree was confirmed by a bootstrap value of 1000 replicates. A phylogenetic tree was rooted using Zingibermontanumas the out-group.

Table 1: Plant Materials Used in the Study

\begin{tabular}{|l|c|l|}
\hline \multicolumn{1}{|c|}{ Sample } & Accession No & \multicolumn{1}{|c|}{ Source } \\
\hline Curcuma aromaticaSalisb. 1 & 18 srRNA1 & Phitsanulok \\
\hline Curcuma aromaticaSalisb. 2 & 18 srRNA31 & Phetchabun \\
\hline Curcuma amadaRoxb. 1 & 18 srRNA5 & Phitsanulok \\
\hline Curcuma amadaRoxb. 2 & 18 srRNA6 & Phitsanulok \\
\hline Curcuma amadaRoxb. 3 & 18 srRNA7 & Phitsanulok \\
\hline Curcuma amadaRoxb. 4 & 18 srRNA10 & Phitsanulok \\
\hline Curcuma comosa Roxb.1 & 18 srRNA4 & Phitsanulok \\
\hline Curcuma ecomata Craib & 18 srRNA29 & Phayao \\
\hline Curcuma roscoeana Wall.* & 18 srRNA26 & Lamphun \\
\hline Curcuma longa L. & 18 srRNA3 & Phitsanulok \\
\hline Curcuma rubescensRoxb & 18 srRNA9 & Phitsanulok \\
\hline Curcuma rubrobracteataSkornickova, Sabu\&Prasanthk. & 18 srRNA42 & Tak \\
\hline Curcuma aeruginosaRoxb. & 18 srRNA44 & Tak \\
\hline
\end{tabular}




\begin{tabular}{|l|c|l|}
\hline \multicolumn{3}{|c|}{ Table 1: Contd., } \\
\hline Curcuma bicolor J. Mood \& K. Larsen & 18 srRNA55 & Lampang \\
\hline Curcuma sp.1 & 18 srRNA43 & Tak \\
\hline Curcuma sp. 2 & 18 srRNA17 & Lampang \\
\hline Curcuma sp.3 & 18 srRNA30 & Lampang \\
\hline Curcuma sp.4 & 18 srRNA40 & Lampang \\
\hline Curcuma sp 5 & 18 srRNA47 & Nakronrachasima \\
\hline Curcuma sp 6 & 18 srRNA16 & Phayao \\
\hline Curcuma sp 7 & 18 srRNA41 & Phitsanulok \\
\hline Curcuma sp 8 & 18 srRNA2 & Phitsanulok \\
\hline Zingibermontanum & 18 srRNA33 & Phitsanulok \\
\hline
\end{tabular}

\section{RESULTS AND DISCUSSIONS}

\section{Sequences Characteristics}

All samples within Curcuma produced amplification products when PCR was performed with the ETS primers using the same protocol (Table 1). The length of ETS varied from $579 \mathrm{bp}$ (C. aeruginosa) to 583 (Curcuma sp. 6, Curcuma sp. 7, C. amada 1 and C. amada 4) and averaged 581 bp. The sequence alignment contained 584 bp and 87 were parsimony informative sites. The CG content was $49.4 \%$ and AT was 50.6\%. Furthermore, the average number of substitutions per site was 0.053 . The sequence alignment showed the nucleotide substitution that occurred in the 3 region of 4 samples $(C$. Bicolor, Curcuma sp. 2, 3 and 4). They shared 40 sites of 1 base substitution site, 4 sites of 2 base substitution site and 1 site of 5 base substitution. Accordingly, to nucleotide substitutions have occurred throughout the 3 region of the ETS the Calycadenia and Osmadenia (Baldwin and Markos, 1998). Interestingly, only 1 insertion was found in some species $(C$. amada 1, 2, 3, 4 and Curcuma sp. 5, 6, 7) (Figure 1)

\section{Phylogenetic Analysis}

NJ tree was constructed using Kimura 2-parameter model of nucleotide substitution. The genetic distance revealed that the species fell in the range of 0.003-0.134 among 22 samples of Curcuma (Table 2). Maximum genetic distance was between Curcuma sp. 5 and C. Bicolor (0.132), while the least genetic distance was found between Curcuma sp. 1 and $C$. aeruginosa as same as $C$. amada 2 and $C$. amada 3 (0.002). The high level of ETS sequences similarity has been found between intragenomic (Poczai and Hyvonen, 2010). Phylogenetic trees obtained in the ETS region showed high support values. Two major clades were identified with $\geq 99 \%$ bootstrap support and Zingibermontanum as the out-group. $C$. Bicolor, Curcuma sp. 2, 3 and 4 were clustered into the same group (100\%) and other samples were placed in the second group (99\%). Curcuma sp. 5, 6, 7 and C. amada 1,2,3,4 was placed within the same sub-clade with strong bootstrap support (97\%) as same as Curcuma sp. 1 and C. aeruginosa (100\%) which were also in accordance with geographical origin. C. amada, C. aromatic and C. comosa were group in the same clade which could be correlated with chromosome number (Skornickova, et al., 2007). This result indicated that the three species were closely related. The result showed that the Zingiber and Curcuma were grouped separately agreement with the study was to examine the genetic diversity among and within two populations of Zingiberaceae (Zingiber and Curcuma) using DNA-based molecular markers such as RAPD, ISSR and SSR (Mohanty, et al., 2014). However, C. aromatic 1 and C. aromatic 2 were placed in the difference sub-clade because $C$. aromatica is a seed setting species and seedling variation may be the reason for the genetic variation in the two samples of C. aromatica (Syamkumar and Sasikumar, 2007)

The results of the present study showed that the ETS primers were highly effective in amplifying and sequencing 
of Curcuma species. The ETS sequences represented that this was a useful region for phylogenetic relationships and genetic diversity studies in Curcuma. Most of the previous studies revealed that the ETS was more variable and phylogenetically informative than the ITS region in some plants (Linder et al., 2000; Logacheva. et al., 2010)
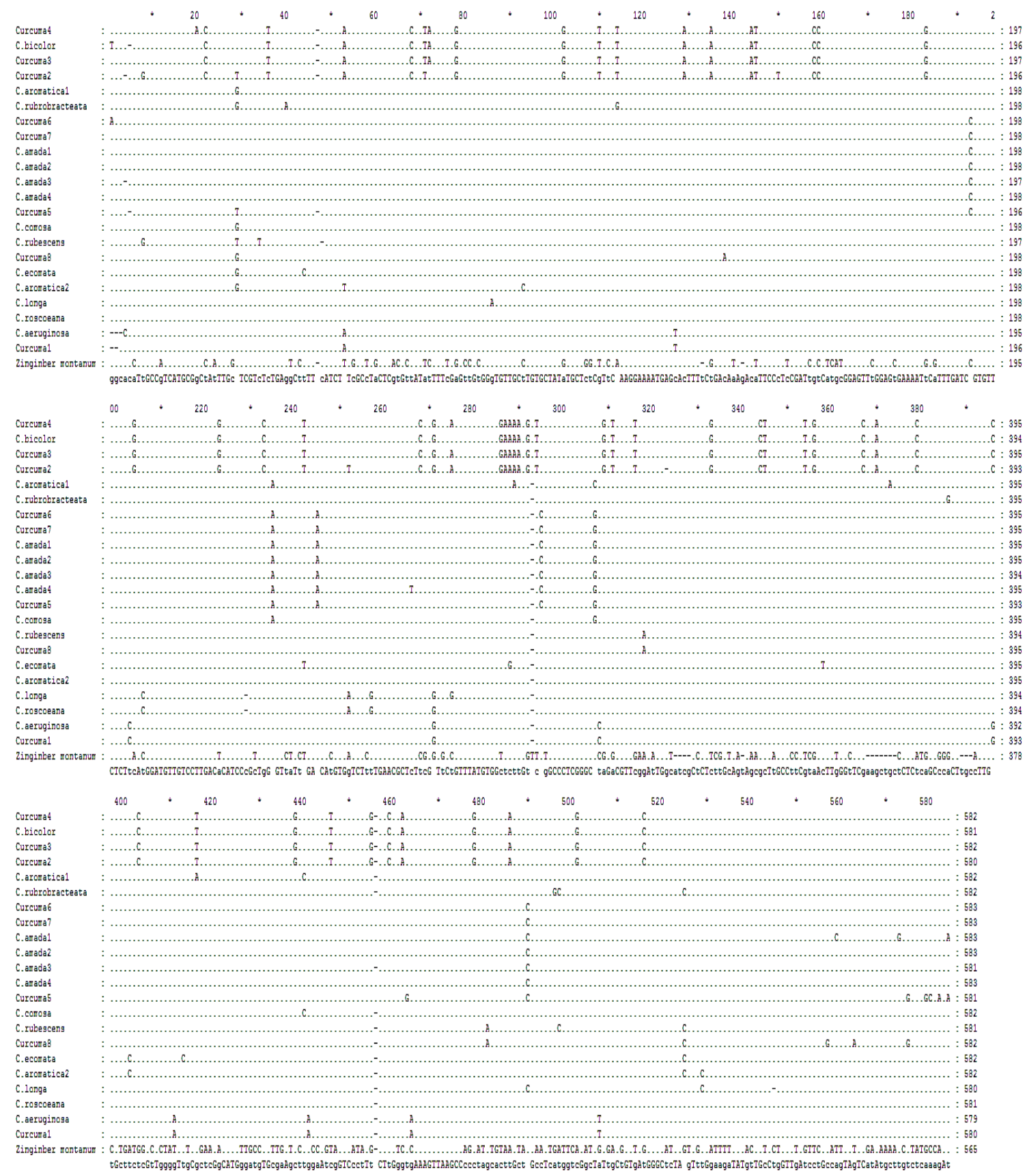

Figure 1: Alignment of ETS Region from 22 Curcuma Samples and Zingibermontanum 


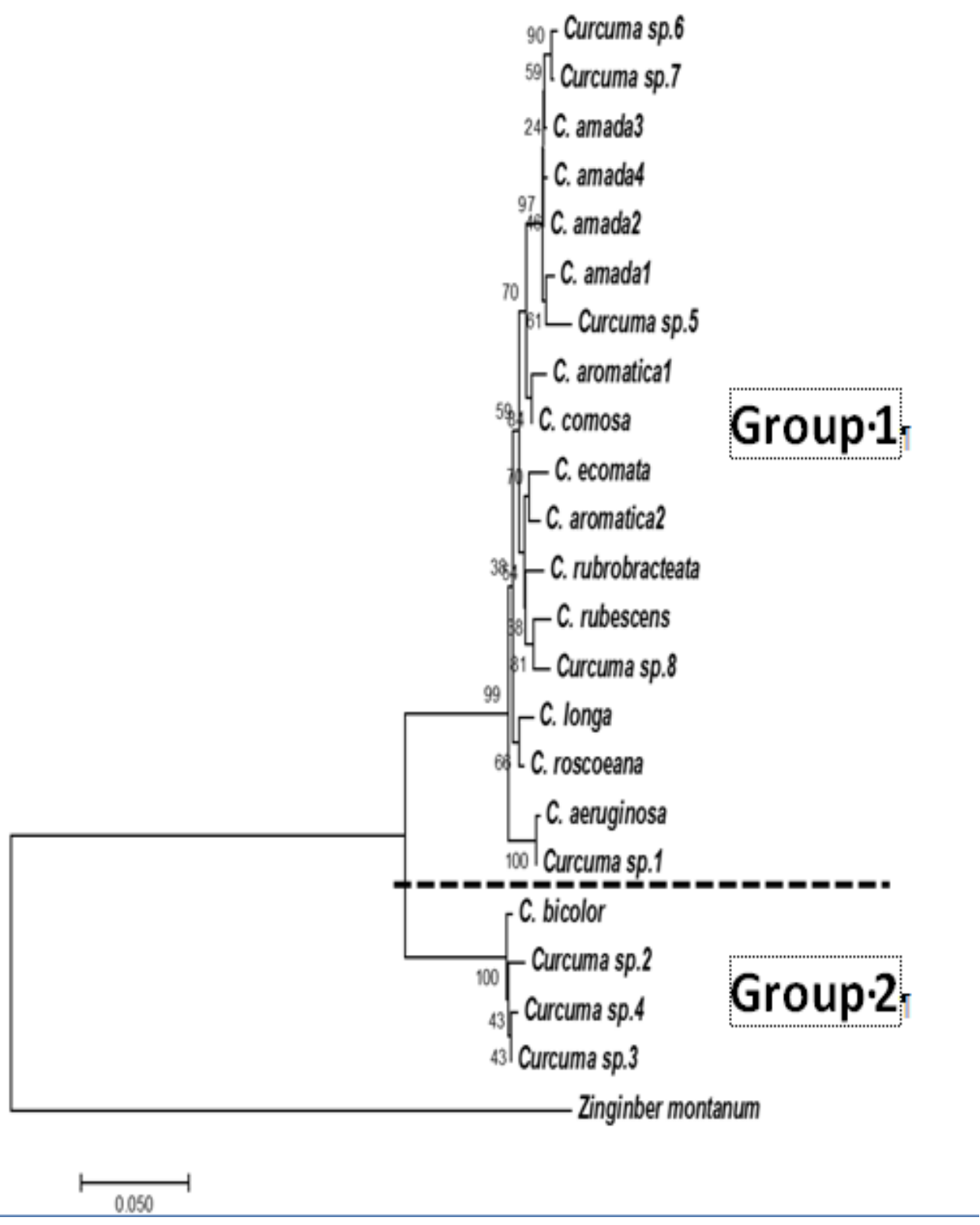

Figure 2: Dendroagram show the Relationships Among the 22 Accession of Curcuma. The Dendrogram was Generated from Similarity Index Based on NJ 
Table 2: Estimate of Evolutionary Divergence between Sequences

\begin{tabular}{|c|c|c|c|c|c|c|c|c|c|c|c|c|c|c|c|c|c|c|c|c|c|c|c|}
\hline 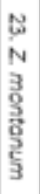 & 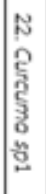 & 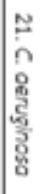 & 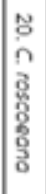 & $\begin{array}{l}\overrightarrow{0} \\
\tilde{y} \\
\bar{s} \\
\widetilde{s}\end{array}$ & 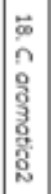 & 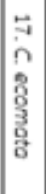 & 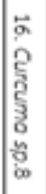 & 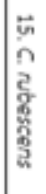 & 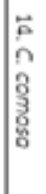 & 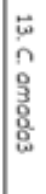 & 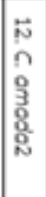 & 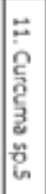 & $\begin{array}{l}\overrightarrow{0} \\
0 \\
0 \\
0 \\
3 \\
8 \\
8 \\
8 \\
8\end{array}$ & \begin{tabular}{|l|}
0 \\
0 \\
0 \\
9 \\
3 \\
6 \\
0 \\
0 \\
\end{tabular} & 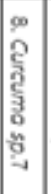 & 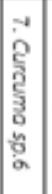 & 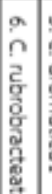 & 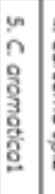 & 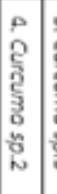 & 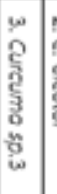 & 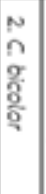 & 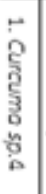 & \% \\
\hline : & 说 & 을 & 웅 & 웅 & 윰 & 웅 & 웅 & 웋 & 完 & 을 & 울 & $\stackrel{\circ}{\ddot{\sharp}}$ & 웅 & 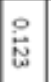 & \begin{tabular}{|l|} 
\\
\end{tabular} & \begin{tabular}{|l|} 
\\
\multirow{2}{*}{} \\
\multirow{\circ}{*}{}
\end{tabular} & 莺 & 울 & 잉 & $\stackrel{8}{8}$ & 음 & & $\rightarrow$ \\
\hline 옹 & 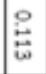 & 웅 & 웅 & 웅 & 웋 & 웅 & 울 & 웅 & 을 & 웋 & 旁 & 영 & 웁 & 웅 & 箁 & 웅 & 总 & 울 & 品 & 용 & & & N \\
\hline 용 & 을 & 을 & 웅 & 总 & 을 & 总 & $\frac{8}{50}$ & 栗 & 웅 & 㤩 & 总 & 웅 & 总 & 울 & 웅 & 용 & 을 & 웅 & 응 & & & & $\omega$ \\
\hline 兽 & 웅 & 윰 & 웅 & 产 & $\stackrel{\circ}{\stackrel{5}{\infty}}$ & 递 & 通 & 윰 & 음 & 웅 & 产 & 웅 & 递 & 这 & 영 & 这 & 융 & $\frac{\mathrm{b}}{\vec{b}}$ & & & & & 0 \\
\hline 응 & 웅 & 응 & 옹 & 옹 & 웅 & 온 & 蓇 & 옹 & 웡 & 응 & $\stackrel{\circ}{\circ}$ & 웅 & 응 & 总 & : & 号 & 옹 & & & & & & in \\
\hline 응 & 용 & 总 & 옹 & 옹 & 임 & 总 & 옹 & 응 & 응 & 웅 & 웅 & 总 & 운 & 总 & 옳 & 용 & & & & & & & $a$ \\
\hline 은 & 总 & 영 & 옳 & 옳 & 商 & 惫 & 畩 & 总 & 을 & 웅 & 웅 & 웅 & 8 & 总 & 8 & & & & & & & & $\sim$ \\
\hline 용 & 总 & 总 & 웅 & 옹 & 옹 & 용 & 융 & 옹 & 응 & 总 & 总 & 응 & 总 & 웅 & & & & & & & & & $\infty$ \\
\hline$\frac{8}{\infty}$ & 용 & 总 & 号 & 옹 & 怘 & 용 & 总 & 总 & 웅 & 웅 & 总 & 웅 & 8 & & & & & & & & & & $\bullet$ \\
\hline 음 & 웅 & 응 & 음 & 옹 & 웅 & 옹 & 胥 & 옳 & 寍 & 용 & 옹 & 웅 & & & & & & & & & & & $\ddot{\circ}$ \\
\hline 응 & 응 & 总 & 웅 & 总 & 웅 & 兽 & 웅 & 웅 & 宓 & 응 & 응 & & & & & & & & & & & & $=$ \\
\hline 온 & 商 & 융 & 응 & 온 & $\stackrel{0}{0}$ & 怘 & 怘 & 옹 & $\stackrel{0}{\circ}$ & 总 & & & & & & & & & & & & & i \\
\hline$\stackrel{ }{2}$ & 通 & 总 & $\stackrel{\circ}{\circ}$ & 옹 & $\stackrel{8}{\circ}$ & 怘 & 总 & 웅 & 总 & & & & & & & & & & & & & & $\dot{\omega}$ \\
\hline 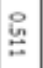 & 通 & 芯 & 응 & 号 & 总 & 号 & 号 & 옹 & & & & & & & & & & & & & & & $\ddot{\Delta}$ \\
\hline 总 & 용 & 융 & 옹 & 용 & 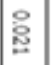 & 总 & $\stackrel{\circ}{\circ}$ & & & & & & & & & & & & & & & & जे \\
\hline 을 & 兽 & 总 & 옹 & 용 & \begin{tabular}{|l|} 
\\
\hdashline
\end{tabular} & 연 & & & & & & & & & & & & & & & & & 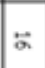 \\
\hline 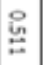 & 总 & 윰 & 怘 & 高 & 음 & & & & & & & & & & & & & & & & & & $\because$ \\
\hline 웅 & 옹 & 윯 & 总 & 옹 & & & & & & & & & & & & & & & & & & & 沜 \\
\hline 영 & 怘 & 8 & 용 & & & & & & & & & & & & & & & & & & & & $: \overrightarrow{0}$ \\
\hline 产 & 온 & 윯 & & & & & & & & & & & & & & & & & & & & & $\stackrel{\circ}{\circ}$ \\
\hline 윰 & 总 & & & & & & & & & & & & & & & & & & & & & & $\cong$ \\
\hline 을 & & & & & & & & & & & & & & & & & & & & & & & $N$ \\
\hline & & & & & & & & & & & & & & & & & & & & & & & $\mathrm{N}$ \\
\hline
\end{tabular}




\section{ACKNOWLEDGMENTS}

This work was financially supported by Naresuan University (R2559C094). We would like to thank Asst. Prof. Dr. Pranee Nangngam for providing plant samples.

\section{REFERENCES}

1. Alonso, A., Bull, R.D. Acedo, C. and Gillespie, L.J. 2014. Design of plant-specific PCR primers for the ETS region with enhanced specificity for tribe Bromeae and their application to other grasses (Poaceae). Botany. 92:693-699.

2. Baldwin, G.B. and Markos, S. 1998. Phylogenetic Utility of the External Transcribed Spacer (ETS) of 18S-26S rDNA: Congruence of ETS and ITS Trees of Calycadenia(Compositae). Molecular Phylogenetics and Evolution.10:449-463.

3. Dhakshanamoorthy, D. and Selvaraj, R. (2009). Extraction of genomic DNA from Jathophasp using modified CTAB methods. Journal of Plant Biology. 54(2): 117-125.

4. Dixon M.T., Hillis D.M. 1993. Ribosomal RNA secondary structure: compensatory mutations and implications for phylogenetic analysis. Molecular Biology and Evolution. 10:256-267.

5. Hidalgo, O., Garcia-Jacas, N., Garnatje, T. and Susanna, A. 2006. Phylogeny of Rhaponticum (Asteraceae, CardueaeCentaureinae) and Related Genera Inferred from Nuclear and Chloroplast DNA Sequence Data: Taxonomic and Biogeographic Implications. Annals of Botany. 97:704-714.

6. Kumar S., Stecher G., and Tamura K. (2016). MEGA7: Molecular Evolutionary Genetics Analysis version 7.0 for bigger datasets.Molecular Biology and Evolution 33:1870-1874.

7. Linder, C.R., Goertzen, L.R., Heuvel, B.V., Francisco-Ortega, J. and Jansen, P.K. 2000. The Complete External Transcribed Spacer of 18S-26S rDNA: Amplification and Phylogenetic Utility at Low Taxonomic Levels in Asteraceae and Closely Allied Families. Molecular Phylogenetics and Evolution. 14:285-303.

8. Logacheva, M.D, Valiejo-Roman, C.M., Degtjareva, G.V., Stratton, J.M., Downie, S.R., Samigullin, T.H. and Pimenov, M.G. 2010. A comparison of nrDNA ITS and ETS loci for phylogenetic inference in the Umbelliferae: An example from tribe Tordylieae. Molecular Phylogenetics and Evolution. 57:471-476.

9. Markos, S. and Baldwin, B. G. 2001. Higher-Level Relationships and Major Lineages of Lessingia (Compositae, Astereae) Based on Nuclear Rdna Internal and External Transcribed Spacers (ITS and ETS) Sequences. Systematic Botany. 26:168-183.

10. Mohanty, S., Panda, M.K., Acharya, L. and Nayak, S. 2014. Genetic diversity and gene differentiation among ten species of Zingiberaceae from Eastern India. Biotech. 4:383-390.

11. Murty, G.S., Patel, F., Punwar, B.S, Patel, M., Singh,,A.S. and Fougat, R.S. (2013). Comparison of RAPD, ISSR and DAMD markers for genetic diversity assessment between accessions of Jatrophacurcas L. and its related species. Journal of Agricultural Science and Technology. 15:1007-1022.

12. C. Krishnamoorthy, K. Soorianathasundaram \& S. Mekala, Effect of Fertigation on FUE, Quality and Economics of Cultivation in Turmeric (Curcuma longa L.) CV. BSR 2, International Journal of Agricultural Science and Research (IJASR), Volume 5, Issue 1, January - February 2015, pp. 67-72

13. Nicholas, K.B., H.B.J. Nicholas and D.W. Deerfield. 1997. GeneDoc: analysis and visualization of genetic variation. EMBNEW NEWS 4: 14.

14. Poczai, P. and Hyvonen, J. 2010. Nuclear ribosomal spacer regions in plant phylogenetics: problems and prospects. Molecular Biology Reports. 37:1897-1912. 
15. Skornickova, J., Sida, O., Jarolimova, V., Sabu M., Fer, T., Travnicek, P. and Suda, J. 2007. Chromosome Numbers and Genome Size Variation in Indian Species of Curcuma (Zingiberaceae). Annals of Botany. 100:505-526.

16. Syamkumar, S. and Sasikumar, B., 2007. Molecular marker based genetic diversity analysis of Curcuma species from India. Scientia Horticulturae. 112:235-241.

17. Thompson, J.D., T.J. Gibson, F. Plewniak, F. Jeanmougin and D.G. Higgins. 1997. The ClustalX windows interface: flexible strategies for multiple sequence alignment aided by quality analysis tools. Nucleic Acids Research. 24: 4876-4882.

18. Wu, D.L. and Larsen, K. 2000. Zingiberaceae In: Flora of China, vol. 24 (eds Wu ZY \& Raven P), pp. 322-377. Science Press, Beijing and Missouri Botanical Garden Press, St. Louis, MO

19. Záveská, E., Fér, T. Šída, O. and Leong-Škorničková, J. 2012. Phylogeny of Curcuma(Zingiberaceae) based on plastid and nuclear sequences: Proposal of the new subgenus Ecomata. Taxon. 61:747-763. 